\title{
Studies on the lysozyme independence of immune immobilisation of Treponema pallidum and the frequency of lysozyme autoantibodies in syphilitic sera
}

\author{
SUSANNE ZIELINSKI and HERTHA-LORE BORKHARDT \\ Institute for Medical Microbiology, Otto von Guericke University of Magdeburg, Leipziger Str. 44, D-39120 \\ Magdeburg, Germany
}

\begin{abstract}
The role of lysozyme in the immune immobilisation of Treponema pallidum is not yet fully understood. The $T$. pallidum immobilisation assay was used to demonstrate that the immobilisation and lysis of $T$. pallidum in vitro by antibodies (serum, IgG fraction or IgM fraction) and complement proceed in a lysozyme-independent mode. In the presence of lysozyme the rate of immobilisation increased. In contrast with its effect on Escherichia coli, the effect of lysozyme on T. pallidum was governed exclusively by its enzymic activity rather than by the cationic protein nature of the molecule. Lysozyme, released from stimulated phagocytes, induced formation of lysozyme antibodies in $\mathbf{5 9 . 6 \%}$ of syphilis patients as determined by lysozyme antibody ELISA. The highest frequency was found in patients with untreated secondary syphilis, whereas untreated primary syphilis was only rarely accompanied by the presence of lysozyme antibodies. Crossreactivities between lysozyme and treponemal antigens were excluded by immunoblotting. The autoantibodies did not influence the lysozyme activity. It was concluded that the formation of lysozyme antibodies is only an epiphenomenon in the host defence against treponemal infection.
\end{abstract}

\section{Introduction}

The enhancing effect of lysozyme on antibody- and complement-mediated immobilisation and lysis of Treponema pallidum has been accepted for $>30$ years $[1,2]$. However, whether there is an absolute requirement for lysozyme in order for irreversible immunologically induced damage of treponemes to occur is not clear. While Born and Bhakdi [3] provided evidence of a lysozyme-independent mechanism of complementmediated bacteriolysis for Escherichia coli, Müller et al. [4] demonstrated that treponemes, which are also gram-negative bacteria, are not killed by antibodies and complement without lysozyme. Only in the presence of lysozyme did they observe irreversible damage of treponemes in the $T$. pallidum immobilisation assay (TPI). In keeping with the results of Radolf et al. [5] and Walker et al. [6] on the limited antigenicity of the T. pallidum outer membrane (there is a 100 -fold lower concentration of epitopes as compared to the outer membrane of other gram-negative bacteria), the kinetics of antibody- and complement-mediated killing

Received 16 July 1996; revised version accepted 29 Dec. 1996. of treponemes is different from the situation with $E$. coli. The process of damage of treponemes by antibodies and complement [7] requires much more time than the immune bacteriolysis of E. coli [8]. Therefore, it seems possible that the few complementinduced holes in the outer membrane of treponemes could be repaired and that the endoflagella could remain inaccessible to immobilising antibodies unless there is additional destruction of the cell wall as a result of the lysozyme influx. This suggests an important potential role for lysozyme in host defence against treponemal infection and, consequently, that a lack of lysozyme could have a direct influence on the course of infection. One possible cause for the deficiency of lysozyme could be an inactivating factor such as antibody. Lysozyme antibodies have not been demonstrated in the serum of patients with syphilis. Such antibodies might influence the enzymic activity of lysozyme and thus delay the immobilisation of treponemes, depending upon the concentration ratio of lysozyme to lysozyme antibody. However, the cationic charge of the enzyme may not be influenced by antibody. Pellegrini et al. [9] showed that the bactericidal effect of lysozyme on $E$. coli is based on its enzymic properties as well as on its cationic protein 
nature. Therefore this study tested the influence of enzymically inactive lysozyme on $T$. pallidum.

\section{Materials and methods}

\section{Animals}

Adult male 'Russian' rabbits were obtained from the Moellegaard breeding centre (Denmark), housed individually at $18-20^{\circ} \mathrm{C}$ and given antibiotic-free food and water. The rabbits were examined by the VDRL test to exclude infection with $T$. paraluiscuniculi.

\section{Bacteria}

T. pallidum ssp. pallidum (Nichols strain) was maintained by intratesticular passage in rabbits without the use of cortisone acetate. Treponemal suspensions were prepared from the testes of rabbits 6-8 days after intratesticular infection; organisms were either extracted into sterile phosphate-buffered saline (PBS) or basal reduced medium for prolonged incubation in vitro (48 h) [10]. Suspensions were centrifuged twice for $10 \mathrm{~min}$ at $500 \mathrm{~g}$ to remove gross testicular debris. The number of motile treponemes in the supernate was counted by dark-field microscopy and adjusted with PBS to $(3-5) \times 10^{7}$ treponemes $/ \mathrm{ml}$ for passage. One $\mathrm{ml}$ of treponemal suspension in PBS was injected into each testis of rabbits. For the immobilisation assay in vitro, the treponemal suspension was adjusted to $2 \times 10^{6} / \mathrm{ml}$ of basal medium.

\section{Lysozyme}

Hen egg white lysozyme (Reanal, Hungary; $10000 \mathrm{U} / \mathrm{mg}$ ) and human milk lysozyme (Sigma; $7900 \mathrm{U} / \mathrm{mg}$ ) were used throughout. The lysozyme activity in sera was measured by means of the lysoplate technique [11], with minor modifications. This method permits the detection of lysozyme at concentrations as low as $0.1 \mu \mathrm{g} / \mathrm{ml}$. Lysozyme was removed from human and guinea-pig sera by absorption with bentonite [8]. The treponemes were washed three times with basal medium to remove lysozyme. Hen egg white lysozyme was inactivated with dithiothreitol (DTT) as described by Pellegrini et al. [9]. Briefly, $5 \mathrm{mg}$ of hen egg white lysozyme was dissolved in $1 \mathrm{ml}$ of $0.01 \mathrm{M} \mathrm{NaH}_{2} \mathrm{PO}_{4}$ / $\mathrm{Na}_{2} \mathrm{HPO}_{4}$ buffer ( $\mathrm{pH}$ 7.4) containing $0.01 \mathrm{M}$ DTT and incubated at $37^{\circ} \mathrm{C}$ for $2 \mathrm{~h}$ until a precipitate was formed. The precipitate was sedimented by centrifugation at $2000 \mathrm{~g}$ for $15 \mathrm{~min}$, washed 10 times in distilled water and freeze-dried. Bentonite-absorbed sera as well as DTT-inactivated hen egg white lysozyme preparations were tested for residual lysozyme activity in the lysoplate technique. Lysozyme activity was no longer detected.

\section{Human sera}

Ninety-nine sera were collected from patients at various stages of untreated and treated syphilis (10 primary, untreated; eight primary, treated; 18 secondary, untreated; 24 secondary, treated; 13 latent; two tertiary; and 24 not classified). Diagnosis was based upon reactive non-treponemal and treponemal serological tests and upon the presence of typical clinical signs. A further 50 normal sera from blood donors were obtained for control purposes. Human syphilitic sera with known immobilisation titres were used for immobilisation experiments. All sera were stored in small volumes at $-70^{\circ} \mathrm{C}$; repeated freezing and thawing were avoided.

\section{Fractionation of immune sera}

Ammonium sulphate precipitated globulins (50\% saturation) from human syphilitic sera were resuspended in PBS, dialysed against PBS overnight and applied to Protein G Sepharose for fast flow (Pharmacia, Sweden). Unbound proteins (IgM fraction) were washed through and $1-\mathrm{ml}$ fractions were collected. Bound IgG antibodies were eluted with $0.1 \mathrm{M}$ glycine $/ \mathrm{HCl}$ buffer $(\mathrm{pH} 2.5$ ). Fractions of $1 \mathrm{ml}$ were collected and immediately neutralised with $1 \mathrm{~N}$ tris (hydroxymethyl) aminomethane (TRIS). Fractions were pooled and the IgG- fraction was dialysed against PBS before both preparations were concentrated.

\section{Complement}

Guinea-pig serum as the complement source was obtained from Harlan.

\section{Lysozyme antibody ELISA}

Microtitration plates (Greiner, Germany) were coated overnight with anti-human lysozyme antibodies (Dako, Denmark) diluted 1 in 400 in $0.1 \mathrm{M}$ carbonate buffer (pH 9.6). After blocking for $2 \mathrm{~h}$ with low-fat milk powder $1 \%$ in PBS, $100 \mu l$ of human milk lysozyme $2.5 \mu \mathrm{g} / \mathrm{ml}$ in PBS was added to each well and incubated for $2 \mathrm{~h}$ at room temperature. The plates were washed three times, control and test sera were diluted in PBS (1 in 20,1 in 40,1 in 80) and $100 \mu \mathrm{l}$ of each dilution was added to replicate wells and incubated for $2 \mathrm{~h}$ at room temperature. For control purposes, to exclude non-specific reactivities, buffer was used instead of human milk lysozyme and human serum. After washing the plates as described above, peroxidase-conjugated rabbit anti-human IgG (Dako) diluted 1 in 500 in PBS was added and incubated for $2 \mathrm{~h}$ at room temperature. The plates were washed three times followed by the addition of substrate which comprised $25 \mu \mathrm{l}$ of $\mathrm{H}_{2} \mathrm{O}_{2} \quad 30 \%$ and $1 \mathrm{mg}$ of tetramethylbenzidine dissolved in $1 \mathrm{ml}$ of ethanol in $9 \mathrm{ml}$ of citrate buffer ( $\mathrm{pH}$ 5.0). The substrate reaction was stopped after $15 \mathrm{~min}$ by adding $50 \mu \mathrm{l}$ of $2 \mathrm{M} \mathrm{H}_{2} \mathrm{SO}_{4}$. The plates were read immediately with a spectrophotometer (Anthos) at $450 \mathrm{~nm}$. The cut-off value was defined as the mean absorbance of 50 negative sera (blood donors) plus 2 SD. 


\section{Immobilisation of treponemes}

The TPI assay was performed by the method of Nelson and Mayer [12]. Lysozyme-free T. pallidum suspension (200 $\mu$ l) containing $2 \times 10^{6}$ bacteria $/ \mathrm{ml}$ was mixed with $50 \mu 1$ of bentonite-absorbed syphilitic serum, or serum fraction and $250 \mu \mathrm{l}$ of bentonite-absorbed guinea-pig serum. Hen egg white lysozyme was added to final concentrations of 0.5 and $5 \mu \mathrm{g} / \mathrm{ml}$. DTTinactivated lysozyme was added at concentrations of 5 and $50 \mu \mathrm{g} / \mathrm{ml}$. To evaluate the influence of lysozyme on treponemes in the absence of antibodies or of both antibodies and complement, hen egg white lysozyme at concentrations of 5,10 or $100 \mu \mathrm{g} / \mathrm{ml}$ was added to treponemes and complement, or to treponemes only.

Aliquots of $0.5 \mathrm{ml}$ of these mixtures were placed into small tubes which were loosely plugged with cotton wool and incubated in an oxygen-reduced atmosphere at $35^{\circ} \mathrm{C}$. The percentage of immobile treponemes was determined after $0,4,8$ and $18 \mathrm{~h}$ by examination of 100 treponemes by dark-field microscopy. Each test was run in duplicate on different days.

\section{SDS-PAGE and immunoblotting}

T. pallidum antigen and human milk lysozyme were electrophoresed on SDS-PAGE $12.5 \%$ gels in a discontinuous buffer system according to Laemmli [13]. For calibration of mol.wt, a low mol.wt calibration kit (Pharmacia) was used. The semi-dry blot system [14] was used to transfer separated proteins on to nitrocellulose membrane $(0.2 \mu \mathrm{m}$, Schleicher and Schuell Co., Germany). The membrane was incubated for $1 \mathrm{~h}$ in PBS containing low-fat milk powder $5 \%$ for blocking. The treponemal antigen and the lysozyme were detected with rabbit anti-treponemal and rabbit anti-lysozyme antibodies, respectively, each diluted 1 in 100 in PBS, followed by incubation with peroxidaseconjugated anti-rabbit antibodies and substrate-reaction with a mixture of $8 \mathrm{mg}$ of 4-chloro-1-naphthol in $4 \mathrm{ml}$ of methanol and $25 \mu \mathrm{l}$ of $\mathrm{H}_{2} \mathrm{O}_{2} 30 \%$ in $6 \mathrm{ml}$ PBS.

\section{Rheumatoid factors}

The presence of rheumatoid factors was determined with a latex agglutination assay ('Rapitex', Behring, Germany) according to the manufacturer's instructions. Results were confirmed by particle enhanced nephelometry (' $\mathrm{N}$ Latex RF', Behring) in the Behring Nephelometer system according to the manufacturer's instructions. The detection limit was $9.1 \mathrm{IU} / \mathrm{ml}$. Sera $>20 \mathrm{IU} / \mathrm{ml}$ were considered as rheumatoid factor positive.

\section{Removal of rheumatoid factors from sera}

Patient serum $(40 \mu \mathrm{l})$ was mixed with $160 \mu \mathrm{l}$ of an aqueous $1 \%$ suspension of polystyrene particles coated with human Gamma-globulin ('RapiTex RF new', Behring) and incubation for $15 \mathrm{~min}$ at $37^{\circ} \mathrm{C}$. Particles were sedimented by centrifugation at $10000 \mathrm{~g}$ for
5 min. The supernate was tested again for rheumatoid factors.

\section{Results}

The rates of immobilisation of $T$. pallidum with a high TPI titre serum (50\% TPI titre 1200) and a low titre serum (50\% TPI titre 40 ) were dependent upon the lysozyme concentration and are shown in Fig. 1. Immobilisation of $T$. pallidum was observed under lysozyme-free conditions. However, the lack of lysozyme had a greater influence on the immobilisation rate with the low-titre serum. Fig. 2 shows the immobilisation rates obtained with an IgM-enriched IgG-free serum fraction and with purified IgG under lysozyme-free conditions and in the presence of hen egg white lysozyme 0.5 and $5 \mu \mathrm{g} / \mathrm{ml}$. Purified treponemal specific IgG as well as the IgM-enriched fraction caused immune immobilisation in the absence of lysozyme. Hen egg white lysozyme inactivated by treatment with DTT had no effect on the immobilisation of T. pallidum at concentrations up to $50 \mu \mathrm{g} / \mathrm{ml}$ (Fig. 3). Therefore, the effect of lysozyme on the

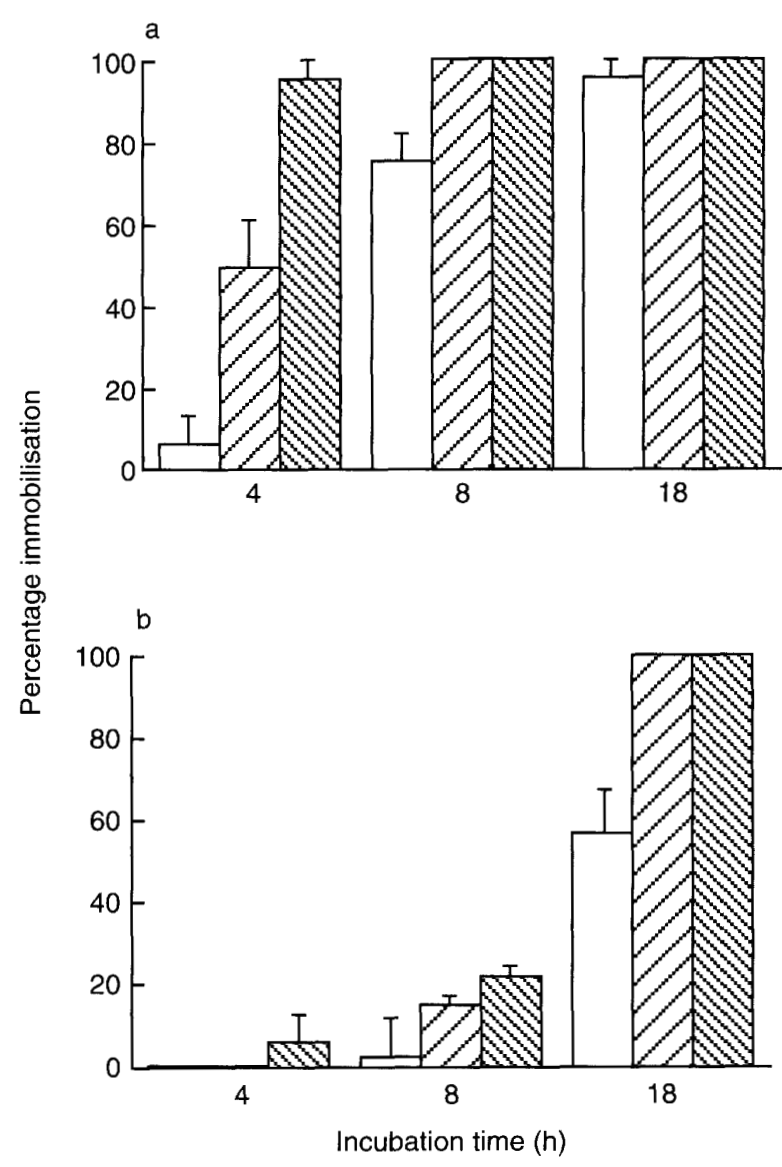

Fig. 1. Immobilisation of $T$. pallidum versus time and concentration of hen egg white lysozyme (HEL: $\square$, $<0.1 \mu \mathrm{g} / \mathrm{ml} ; \square, 0.5 \mu \mathrm{g} / \mathrm{ml} ; \circlearrowleft, 5 \mu \mathrm{g} / \mathrm{ml}$ ) in the presence of complement and (a) high TPI titre serum (50\% immobilisation titre 1200) and (b) low TPI titre serum $(50 \%$ immobilisation titre 40$)$ (mean and $\mathrm{SD}, \mathrm{n}=8$ ). 


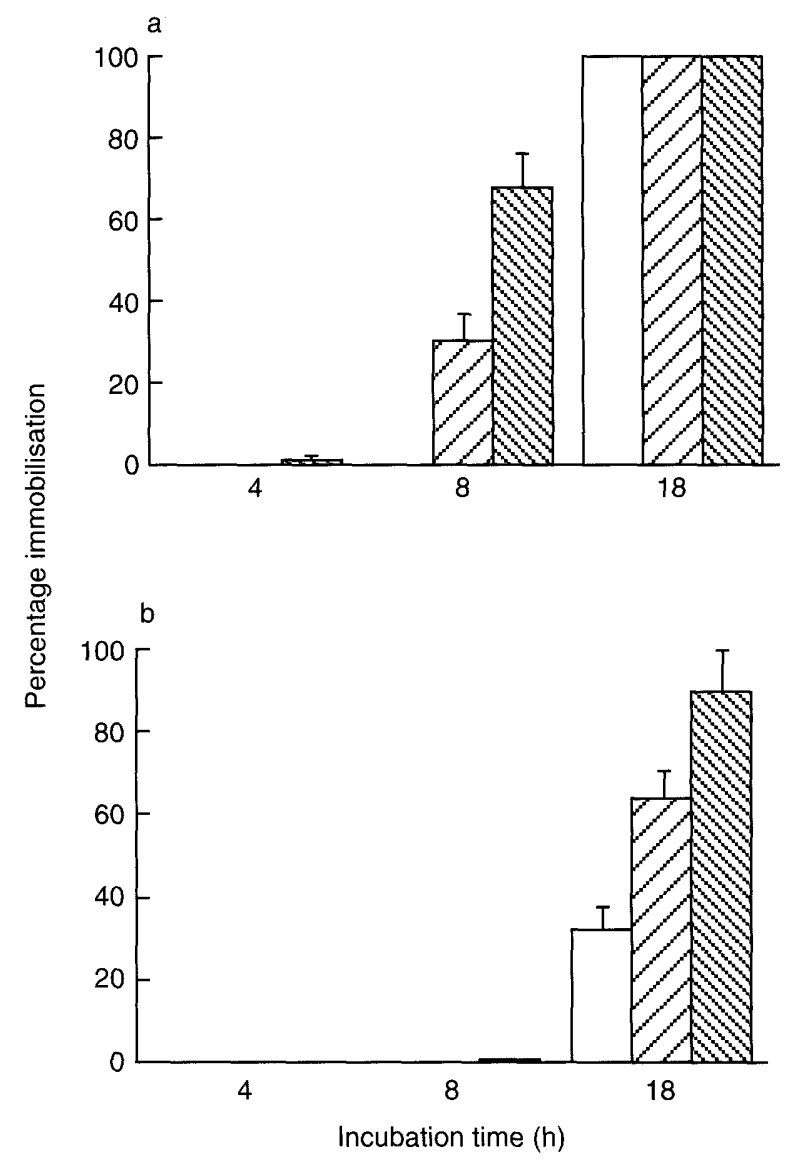

Fig. 2. Immobilisation of $T$. pallidum versus time and concentration of hen egg white lysozyme (HEL: $\square$, $0.1 \mu \mathrm{g} / \mathrm{ml} ; \square, 0.5 \mu \mathrm{g} / \mathrm{ml} ; \Omega, 5 \mu \mathrm{g} / \mathrm{ml})$ in the presence of complement and (a) purified treponemal specific IgG and (b) purified treponemal specific $\operatorname{IgM}$ (mean and $\mathrm{SD}$, $\mathrm{n}=6$ ).

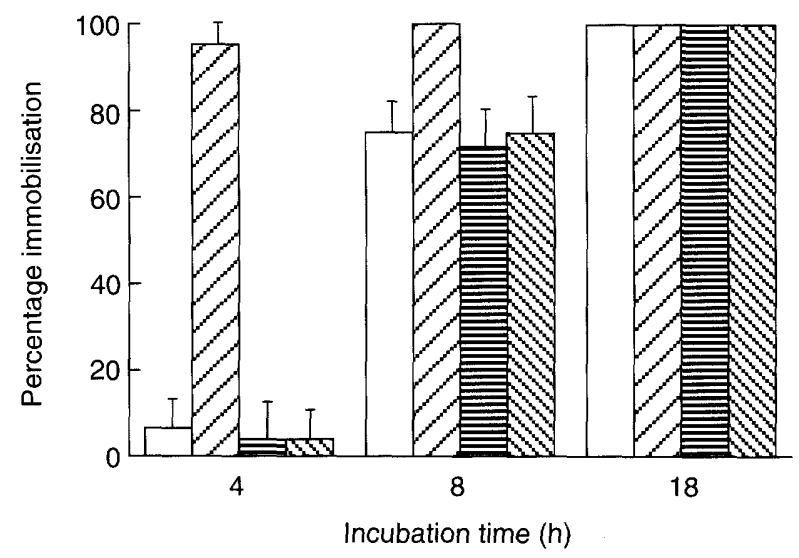

Fig. 3. Effect of enzymically inactive lysozyme (DTTlysozyme: $\mathbb{I I}, 5 \mu \mathrm{g} / \mathrm{ml} ; \mathrm{\Omega}, 50 \mu \mathrm{g} / \mathrm{ml}$ ) on the immobilisation of $T$. pallidum by $T$. pallidum immune serum $(50 \%$ immobilisation titre 1200) in comparison with the effect of enzymically active $(\square, 5 \mu \mathrm{g} / \mathrm{ml})$ and no lysozyme $(\square$, $<0.1 \mu \mathrm{g} / \mathrm{ml}$ ) (mean and $\mathrm{SD}, \mathrm{n}=6$ ).

immune immobilisation of $T$. pallidum was mediated exclusively through the enzymically active form. In the absence of treponemal antibodies and complement, enzymically active lysozyme at concentrations of 5, 10 and $100 \mu \mathrm{g} / \mathrm{ml}$ did not influence the mobility of treponemes. After incubation for $18 \mathrm{~h}, 100 \%$ of treponemes were mobile with each lysozyme concentration compared to the control without lysozyme. Even in the presence of an excess of active complement but in the absence of treponemal specific antibodies, lysozyme $100 \mu \mathrm{g} / \mathrm{ml}$ failed to affect the mobility of T. pallidum and $100 \%$ of treponemes remained mobile after $18 \mathrm{~h}$.

Fifty-nine of 99 sera from patients with syphilis and one of 50 sera from healthy blood donors were active in the lysozyme antibody ELISA. In the sera from patients with untreated secondary syphilis, $100 \%$ reactivity was observed, but only $30 \%$ reactivity was noted at the untreated primary stage. Twenty-eight of the 59 lysozyme antibody-positive sera of syphilis patients were tested for rheumatoid factors. A positive result was obtained with $39.3 \%$ (11 of 28 ) of the sera. None of 28 sera from 40 syphilis patients with a negative lysozyme antibody ELISA result had rheumatoid factors. False positive results in the lysozyme antibody ELISA caused by rheumatoid factors were excluded. The removal of rheumatoid factors from lysozyme antibody-positive sera did not lead to a loss of reactivity in the lysozyme antibody ELISA. Crossreactions between lysozyme and $T$. pallidum antigen were excluded by immunoblotting. No bands were observed when $T$. pallidum antigen was incubated with lysozyme antibodies, and similarly when human lysozyme was incubated with treponemal specific antibodies. Lysozyme antibody-positive serum showed a similar course of immobilisation to lysozyme antibody-negative serum (Fig. 4). A concentration of

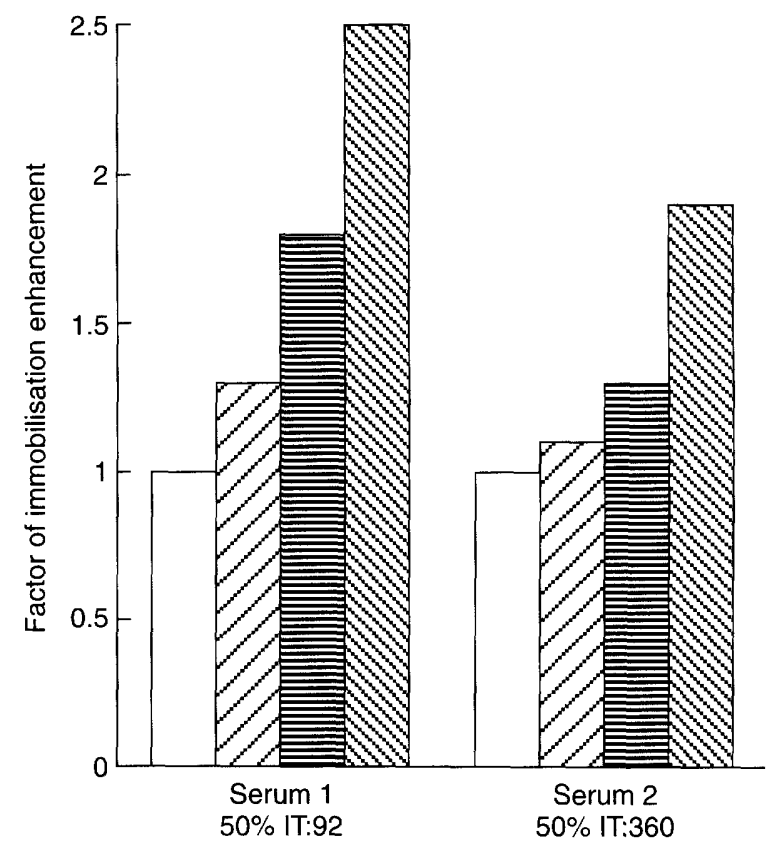

Fig. 4. Effect of human lysozyme (HuL: $\square$, none; $\square$, $0.1 \mu \mathrm{g} / \mathrm{ml} ; \mathrm{Il}, 0.5 \mu \mathrm{g} / \mathrm{ml} ; \mathrm{\Omega}, 1 \mu \mathrm{g} / \mathrm{ml})$ on the rate of immobilisation of $T$. pallidum in the presence of lysozyme-antibody positive syphilitic serum (serum 1) and lysozyme-antibody negative syphilitic serum (serum 2 ). Both sera were rheumatoid factor negative. 
human as lysozyme as low as $0.1 \mu \mathrm{g} / \mathrm{ml}$ caused an increase in the immobilisation rate in the lysozyme antibody-containing serum as well as in the lysozyme antibody-free serum.

\section{Discussion}

The mechanism of antibacterial activity of lysozyme is only partly understood [15]. It is well established that lysozyme hydrolyses the 1,4 $\beta$-glycosidic bond between $\mathrm{N}$-acetyl-glucosamine and $\mathrm{N}$-acetylmuramic acid in the murein layer. Furthermore, Pellegrini and co-workers $[9,16]$ found bactericidal activity resulting from the cationic nature of the protein in the cytoplasm of $E$. coli independent of enzymic activity. The present study revealed that lysozyme exerted an exclusively enzymic effect on $T$. pallidum. DTT-treated enzymically inactive lysozyme did not influence the lysis of treponemes in the TPI assay. A further difference between $E$. coli and T. pallidum in the mechanism of lysozyme action is that lysozyme acts on treponemes only in the presence of antibodies and complement. In contrast to $T$. pallidum $[2,4]$, lysozyme can penetrate into $E$. coli through the outer membrane and cell wall independent of antibody- and complement-mediated damage [9]. This finding may be attributed to the lack of lipopolysaccharide (LPS) in the outer membrane of T. pallidum [17]. The bactericidal permeability-increasing protein (BPI) which is released from granulocytes binds to the LPS of gram-negative bacteria and causes destruction of the barrier function of the outer membrane [18] which, in turn, permits an antibodyand complement-independent lysozyme influx into the cell. This membrane-destabilising effect of BPI does not operate with $T$. pallidum and, hence, the preconditions for an antibody- and complement-independent lysozyme influx do not exist. An essential role for lysozyme in addition to treponemal specific antibodies and complement for immobilisation and lysis of T. pallidum was not detectable in vitro. Thus, the present results obtained with treponemicidal antibodies in sera from infected rabbits or patients with syphilis are consistent with the data reported by Engelkens et al. [19] for natural antibodies with immobilising activity in normal human serum. Hederstedt first described these antibodies in $80 \%$ of healthy individuals $[20,21]$. In contrast to the treponemicidal antibodies from patients with syphilis, these natural antibodies, which are not yet well characterised, belong predominantly to the IgM class [21]. Müller et al. [4] used only the IgG fraction from human syphilitic sera, but did not demonstrate the role of lysozyme in the immobilisation of treponemes by treponemal specific IgM. Engelkens et al. [19] studied the $\operatorname{IgG}$ and IgM fractions with immobilising activity from normal human serum. The results of the present study clearly show the in-vitro independence of $T$. pallidum immobilisation by separated treponemicidal IgG and IgM from lysozyme. The possibility that antibodies, complement and lysozyme might have predamaged the treponemes during their passage in the rabbit testes was ruled out by controls. The lower the concentration of immobilising antibodies, the more pronounced was the quantitative dependence of the kinetics of immobilisation on the lysozyme concentration. IgM-immobilising antibodies exhibited a longer delay before immobilisation in the absence or in the presence of low lysozyme concentrations than did IgG. Immobilising antibodies that attack the endoflagella of treponemes are known to enter the periplasmic space. The murein layer of the bacterium, which is connected to the outer membrane, undergoes lysozyme-enhanced destruction and this results in the destabilisation of the membrane. Under lysozyme-free conditions this process requires more time than it does in the presence of an excess of lysozyme. We propose that $\operatorname{IgM}$ antibodies, due to their size, require a more pronounced destruction of the outer membrane than IgG antibodies in order for penetration into the periplasmic space to take place. If this hypothesis is correct, lysozyme would be particularly important in the early stages of infection (high IgM levels), whereas in the ongoing immune response IgG becomes predominant and the importance of lysozyme would be diminished. The most effective killing of treponemes is likely to take place with a combination of treponemal outer-membrane-specific IgM and endoflagella-specific IgG. Engelkens et al. [18] have postulated that the course of treponemal immobilisation begins with the primary disintegration of the outer membrane by IgM and complement; this in turn is followed by the degradation of murein by lysozyme and immobilisation of endoflagella by IgG.

Lysozyme antibodies were studied to determine whether they influenced lysozyme activity. Schmitt et al. [22] recently described the occurrence of lysozyme antibodies in the sera of patients with inflammatory renal, bowel and rheumatological diseases. The present study demonstrated the existence of lysozyme antibodies in $59.6 \%$ of syphilis patients for the first time. The fact that lysozyme antibodies in syphilis sera did not influence the kinetics of the TPI assay even in the presence of low concentrations of lysozyme $(0.1 \mu \mathrm{g} / \mathrm{ml})$ excludes a detectable neutralising effect of these autoantibodies. Therefore, the likelihood that lysozyme is inhibited by lysozyme antibodies in the serum of syphilis patients is negligible. Hence, it is unlikely that the elimination of bacteria from the infected host is impaired in patients with lysozyme antibodies. The occurrence of rheumatoid factors in $39.3 \%$ of syphilis patients with lysozyme antibodies is a further example of an autoimmune component in syphilis and has been reported previously by Baughn et al. [23]. It remains unclear whether or not, and how, these autoantibodies are involved in the pathogenesis of $T$. pallidum infection.

H.-L. B. and S. Z. were supported by the Ministerium für Wissenschaft und Forschung des Landes Sachsen-Anhalt. 


\section{References}

1. Kent JF, De Weerdt JB. Enhancement by lysozyme of the sensitivity of Treponema pallidum immobilization tests. $\mathrm{Br} J$ Vener Dis 1963; 39: 37-40.

2. Metzger M, Hardy PH, Nell EE. Influence of lysozyme upon the treponeme immobilization reaction. Am J Hyg 1961; 73 236-244

3. Born J, Bhakdi S. Does complement kill E. coli by producing transmural pores? Immunology 1986; 59: 139-145.

4. Müller F, Feddersen H, Segerling M. Studies on the action of lysozyme in immune immobilization of Treponema pallidum (Nichols strain). Immunology 1973; 24: 711-719.

5. Radolf JD, Norgard MV, Schulz WW. Outer membrane ultrastructure explains the limited antigenicity of virulent Treponema pallidum. Proc Natl Acad Sci USA 1989; 86: 2051-2055.

6. Walker EM, Zampighi GA, Blanco DR, Miller JN, Lovett MA. Demonstration of rare protein in the outer membrane of Treponema pallidum subsp. pallidum by freeze-fracture analysis. J Bacteriol 1989; 171: 5005-5011.

7. Blanco DR, Walker EM, Haake DA, Champion CI, Miller JN, Lovett MA. Complement activation limits the rate of in vitro treponemicidal activity and correlates with antibody-mediated aggregation of Treponema pallidum rare outer membrane protein. J Immunol 1990; 144: 1914-1921.

8. Wardlaw AC. The complement-dependent bacteriolytic activity of normal human serum. I. The effect of $\mathrm{pH}$ and ionic strength and the role of lysozyme. $J$ Exp Med 1962; 115: 1231-1249.

9. Pellegrini A, Thomas U, von Fellenberg R, Wild P. Bactericidal activities of lysozyme and aprotinin against gram-negative and gram-positive bacteria related to their basic character. $J$ Appl Bacteriol 1992; 72: 180-187.

10. Berlinghoff W. Über ein neues Überlebensmedium für die Treponemen beim Treponema-pallidum-Immobilisationstest (Nelson-Test). Dermatol Wochenschr 1956; 133: 318-321.

11. Stelzner A, Werle M. Untersuchungen zur Standardisierung der Lysoplate-Technik für den Lysozym-Nachweis. [Investigations on the standardization of the lysoplate technique for assay of lysozyme.] Allerg Immunol 1989; 35: 51-58.

12. Nelson RA J, Mayer MM. Immobilization of Treponema pallidum in vitro by antibody produced in syphilitic infection. $J$ Exp Med 1949; 89: 369-393.

13. Laemmli UK. Cleavage of structural proteins during the assembly of the head of bacteriophage T4. Nature $1970 ; 227$ : $680-685$.

14. Towbin H, Staehelin T, Gordon J. Electrophoretic transfer of proteins from polyacrylamide gels to nitrocellulose sheets: procedure and some applications. Proc Natl Acad Sci USA 1979; 76: 4350-4354.

15. Cottagnoud P, Tomasz A. Triggering of pneumococcal autolysis by lysozyme. J Infect Dis 1993; 167: 684-690.

16. Pellegrini A, Grob K, von Fellenberg R. Identification of a bactericidal component active against Gram-positive and Gramnegative bacteria in commercial ovomucoid and ovoinhibitor as lysozyme. Lett Appl Microbiol 1990; 10: 201-204.

17. Musher DM. Biology of Treponema pallidum. In: Holmes KK, Mardh P-A, Sparling PF et al. (eds) Sexually transmitted diseases. Maidenhead, McGraw-Hill Inc. 1990; 205-211.

18. Elsbach P, Weiss J, Levy O. Integration of antimicrobial host defenses: role of the bactericidal/permeability increasing protein. Trends Microbiol 1994; 2: 324-328.

19. Engelkens HJH, Kant M, Onvlee PC, Stolz E, van der Sluis JJ. The importance of different components of normal human serum and lysozyme in the rapid immobilisation of purified Treponema pallidum, Nichols strain. Genitourin Med 1993; 69: 280-285.

20. Hederstedt B. Studies on the Treponema pallidum immobilizing activity in human normal serum. I. A method. Acta Pathol Microbiol Scand B Microbiol Immunol 1974; 82: 185-200.

21. Hederstedt B. Studies on the Treponema pallidum immobilizing activity in normal human serum. 2. Serum factors participating in the normal serum immobilization reaction. Acta Pathol Microbiol Scand C 1976; 84: 135-141.

22. Schmitt WH, Csernok E, Flesch BK, Hauschild S, Gross WL. Autoantibodies directed against lysozyme: a new target antigen for anti-neutrophil cytoplasmic antibodies (ANCA). $A d v \operatorname{Exp}$ Med Biol 1993; 336: 267-272.

23. Baughn RE, McNeely MC, Jorizzo JL, Musher DM. Characterization of the antigenic determinants and host components in immune complexes from patients with secondary syphilis. $J$ Immunol 1986; 136: 1406-1414. 